\title{
MINERAL RESOURCE POTENTIAL OF THE SUGARLOAF ROADLESS AREA, ESMERALDA AND MINERAL COUNTIES, NEVADA
}

\author{
SUMMARY REPORT
}

By

Edwin H. McKee, James L. Donahoe, and Maurice A. Chaffee

U.S. Geological Survey

and

Steven W. Schmauch, Michael C. Horn, and Richard A. Winters

U.S. Bureau of Mines

\section{STUDIES RELATED TO WILDERNESS}

Under the provisions of the Wilderness Act (Public Law 88-577, September 3, 1964) and related acts, the U.S. Geological Survey and the U.S. Bureau of Mines have been conducting mineral surveys of wilderness and primitive areas. Areas of ficially designated as "wilderness," "wild," or "canoe" when the act was passed were incorporated into the National Wilderness Preservation System, and some of them are presently being studied. The act provided that areas under consideration for wilderness designation should be studied for suitability for incorporation into the Wilderness System. The mineral surveys constitute one aspect of the suitability studies. The act directs that the results of such surveys are to be made available to the public and be submitted to the President and the Congress. This report discusses the results of a mineral survey of the Sugarloaf Roadless Area (5296), Inyo National Forest, Esmeralda and Mineral Counties, Nevada. Sugarloaf Roadless Area was classified as a further planning area during the Second Roadless Area Review and Evaluation (RARE II) by the U.S. Forest Service, January 1979.

\section{SUMMARY}

Geologic, geochemical, mineral, and mines and prospects investigations were conducted to evaluate the mineral resources of the Sugarloaf Roadless Area in Esmeralda and Mineral Counties, Nev., (fig. 1). The principal metallic mineral resources are silver, gold, and mercury, with low potential for lead, zinc, and copper resources. The nonmetallic mineral fluorite (fluorspar) occurs locally. Alunite (potassium aluminum sulfate) formed by alteration of the silicic volcanic rocks is widespread in the southeastern part of the area. Several areas of alteration and mineralization suggest that there is potential for undiscovered mineral resources not identified by surface exploration.

The southwestern part of the area around Queen Canyon has a moderate resource potential for silver and a low resource potential for lead, zinc, and copper. The Indian Queen-Poorman mine is the largest of several past producers in this area and contains 180,000 tons of measured and inferred low-grade resources averaging $2 \mathrm{oz}$ silver per ton. The north-central part of the area south of Sugarloaf mountain has a low potential for gold resources. The Tip Top mine, adjacent to the roadless area, was the largest gold producer in the area. The Brownie mine within the roadless area contains 8,800 tons of indicated and inferred lowgrade resources averaging $0.21 \mathrm{oz}$ gold per ton. The eastern part of the roadless area has a low resource potential for mercury at a number of localities and some gold occurs in this area as well. The Red Rose and the F and L mercury mines have had small production and a number of other mines southeast of the roadless area have had significant mercury production. The $\mathrm{F}$ and $\mathrm{L}$ mine contains 200,000 tons of rhyolite averaging $0.8 \mathrm{lb}$ mercury per ton. At several localities along the west boundary of the roadless area fluorite is found and has been mined at one place outside the roadless area (King-Blue Bell mine).

\section{INTRODUCTION}

Area description

The Sugarloaf Roadless Area covers $17.5 \mathrm{mi}^{2}$ in the northern part of the White Mountains in Esmeralda and Mineral Counties, Nev. It is about $45 \mathrm{mi}$ north of Bishop, Calif., via U.S. Highway 6. Access is by unpaved roads leading eastward into Queen Canyon and southward from Montgomery Pass. The highest point in the roadless area is Mustang Mountain, $10,288 \mathrm{ft}$ above sea level, located in the western part of the area. Queen Valley, on the west edge of the roadless area at the north end of Owens Valley, has an elevation of $6,400 \mathrm{ft}$ above sea level. The region is arid, lying in the rain shadow of the Sierra Nevada which is located about $40 \mathrm{mi}$ to the west. Vegetation is typical of the transition climatic zone and consists of sage and rabbitbrush with sparse grass at lower elevations and pinon and juniper at higher elevations. Willows and wild roses are prolific around springs and flowing streams.

Previous and present investigations

Information on early mining activity and production in the area is in Whitehill (1875-76), Whiting (1888), Lincoln (1923), Bailey and Phoenix (1944), and Horton (1961). Geologic maps of the area include Crowder and others (1973), Robinson and Crowder (1973), and McKee (1982). A map outlining drainages with geochemical anomalies in the roadless area is that of Donahoe and Chaffee (1983).

Geologic and geochemical investigations for this report were done in $1980-82$ by the U.S. Geological Survey. The U.S. Bureau of Mines collected mineral-related information from published and unpublished literature, from the U.S. Bureau of Mines production files, county mining records, and from the U.S. Forest Service and U.S. Bureau of Land Management files. Field studies were carried out during the summer of 1982 to evaluate 36 mining properties in or near the roadless area and a total of 647 samples were collected for analysis. Detailed descriptions of mining properties from this area are in Schmauch and others (1983).

\section{GENERAL GEOLOGY}

Rocks of the northern White Mountains in the area that includes the Sugarloaf Roadless Area range from Cambrian to Quaternary in age. The oldest rocks are metamorphosed strata, now phyllite, slate, and marble, that 
are correlated with Cambrian strata from the southern part of the White Mountains (Crowder and others, 1973). Limestone, shale, and chert of the Ordovician Palmetto Formation are in thrust contact with these Cambrian rocks. Mesozoic plutonic rocks of the Inyo batholith, an eastern part of the Sierra Nevada batholith, intrude the Paleozoic rocks. Lying unconformably on the Mesozoic granitic and Paleozoic metasedimentary rocks are late Cenozoic volcanic rocks and unconsolidated sedimentary deposits.

\section{Sedimentary and metamorphic rocks}

An undetermined thickness of low-grade metamorphic rocks crops out in the Queen Canyon area and elsewhere locally in the northern part of the White Mountains. These rocks are now mostly phyllite, spotted hornfels, and marble and are considered by Crowder and others (1973) most likely to be the Lower Cambrian Poleta and Harkless Formations. They are in thrust contact with the Ordovician Palmetto Formation.

The Palmetto Formation of Ordovician age consists of black chert, dark siltstone, and rhythmically alternating beds of brown fine-grained limestone that is now metamorphosed to marble. The dark fine-grained lithology of the formation indicates deep-water sedimentation and contrasts sharply with the limestone and sandstone shallow marine facies of the Cambrian rocks in the White Mountains.

\section{Plutonic rocks}

About one-half of all the rocks exposed in the White Mountains are granitic types of the multipluton Inyo batholith. Small parts of two of these plutons lie within the Sugarloaf Roadless Area.

Hornblende diorite of the Triassic and (or) Jurassic Queen Canyon pluton, one of the smallest plutons in the Inyo batholith, covers less than $0.5 \mathrm{mi}^{2}$ within the roadless area on the south side of Queen Canyon. The hornblende diorite of Queen Canyon is a heterogeneous medium- to fine-grained hornblende diorite cut by dikes of biotite-hornblende granodiorite, and less commonly by granitic and alaskite dikes.

The Pellisier Flat pluton of Jurassic age crops out over an area of about $60 \mathrm{mi}^{2}$ in the northern part of the White Mountains. About $1 \mathrm{mi}^{2}$ lies within the Sugarloaf Roadless Area in the area around Brownie Creek. This pluton is composed of medium- to coarse-grained biotite-hornblende quartz monzonite to granite. Fine-grained leucocratic granite, aplite, and pegmatite dikes are scattered throughout this pluton.

\section{Stratified and hypabyssal rocks}

Cenozoic volcanic and sedimentary rocks make up most of the Sugarloaf Roadless Area. These rocks include rhyolitic, andesitic, and basaltic lava flows, rhyolitic ash flows, and a variety of rhyolitic and andesitic agglomeratic and clastic volcanogenic sedimentary rocks. Rhyolite flows, tuff, and tuffaceous sandstone are the most widespread rocks in the roadless area. These units are the products of small exogenous volcanoes and are thickest near their vents. The units are lenticular and are interbedded with a wide variety of sedimentary and other volcanogenic rock types. The rhyolitic rocks weather to shades of pink, lavender, and gray, and zones of dark glass are common at the contact with older rocks. The lava flows and shallow intrusive bodies are typically aphanitic and contain less than 5 percent phenocrysts of quartz, sanidine, oligoclase, biotite, and hornblende. Silicification, alunitization, zeolitization, and other types of alteration are locally pervasive. Rhyolitic tuff and tuff-breccia are white to light gray, thin to thick bedded, and poorly sorted. They typically contain crystals of quartz, sanidine, and biotite in a groundmass of mostly devitrified glass shards.

Andesite occurs as lenticular randomly interbedded lava flows, agglomerate, tuff, and tuffaceous sedimentary rocks. Typically these rocks are dark-brown to gray porphyritic plagioclase-pyroxene or hornblende andesite.
Agglomerate consists of poorly sorted angular fragments of andesite in a matrix of brown to lavender mud, silt, and sand. Basalt lava flows form a cap on the northernmost part of the White Mountains north of the Sugarloaf Roadless Area and on Mustang Mountain within the area. The flows are medium to dark gray or brown, fine grained, and locally vesicular. Phenocrysts of olivine, plagioclase, and pyroxene are locally present in an intergranular groundmass of plagioclase, clinopyroxene, olivine, magnetite, and devitrified glass.

\section{Structure}

Structures in the northern White Mountains can be classified in three groups on the basis of style and age. From oldest to youngest, the groups are: (1) thrust faults, thought to have been formed during the middle Paleozoic Antler orogeny, which brought the Ordovician rocks into the White Mountains region irom as much as $40 \mathrm{mi}$ to the northwest; (2) small and large open folds, high-angle faults, and some contact metamorphism that is related to emplacement of Jurassic and Cretaceous granitic rocks of the Inyo batholith; and (3) late Tertiary to Holocene uplift of the range by highangle normal faulting. This basin and range uplift accelerated erosion during the latter part of the Tertiary. Faults of this type are presently active.

Most of the large-scale structural features in the Sugarloaf Roadless Area are covered by a thick mantle of Tertiary volcanic and sedimentary rocks. Shear zones in the Tertiary rocks are poorly defined and generally of small scale. Faults or shear zones are recognized in Tertiary rocks at the Brownie mine and at a number of places in the eastern part of the area. These features are not shown in the geologic map as they are too small to be represented at a scale of $1: 62,500$.

\section{GEOCHEMICAL STUDIES}

Samples of rock, stream sediment, and nonmagnetic heavy-mineral concentrates collected by the U.S. Geological Survey were analyzed for 31 elements using a six-step semiquantitative emission spectrographic method (Grimes and Marranzino, 1968). Because of the limited amount of each sample, the nonmagnetic heavy-mineral concentrate was only analyzed spectrographically. All the rock and streamsediment samples were also analyzed for zine by atomicabsorption spectrometry (Ward and others, 1969); some of these samples were analyzed for gold by the same technique (Meier, 1980). Stream-sediment samples were also analyzed for uranium using a modification of the fluorimetric method of Centanni and others (1956). Results of the analyses and their geochemical interpretation are given by Donahoe and Chaffee (1983).

Of the as many as 34 elements determined in the three types of samples, 10 were selected from the stream-sediment samples and 18 were selected from the samples of nonmagnetic heavy-mineral concentrate as possibly being related to hydrothermal alteration and (or) mineralization. A background and anomaly range and a threshold value (highest background value) for these elements were selected on the basis of a visual inspection of a frequency distribution plot. The threshold values for the Sugarloaf Roadless Area were also compared with those determined in a much larger region north of the study area-the Walker Lake $1^{\circ}$ by $2^{\circ}$ quadrangle. For the sediment and concentrate samples, the anomalously high concentrations for each selected element were assigned to one of two or three concentration-range categories in order to better identify weakly, moderately, or strongly anomalous samples. Drainage basins with anomalous samples were assigned a numerical score based on the number of anomalous elements and their concentration levels (Donahoe and Chaffee, 1983). In general, the higher the anomaly score for a site, the more significant is that site (and drainage basin) in terms of mineral potential.

\section{MINING HISTORY AND MINING ACTIVITY}

Formed in 1862, the Oneota was the first mining 
district which included part of the Sugarloaf area. This district was soon abandoned, but it was reorganized after the discovery and development of the Indian Queen mine in 1870 (Lincoln, 1923). The Oneota district was also known as the Mount Montgomery, Basalt, Queens, and Buena Vista district. A less well-known mining district that covered all or part of the study area was the White Mountain district.

Mining activity and production were mostly in three parts of the study area: Queen Canyon, Sugarloaf mountain, and Trail Canyon. Prospecting in Queen Canyon began in 1862 , but it was not until the discovery of the Indian Queen mine in 1870 that interest in the area became significant. By 1873, a four-stamp mill was processing silver, gold, and lead ore. Several more mines were developed in Queen Canyon, and intermittent production was reported from them from 1873 to 1930. During the next 50 years the Indian Queen mine was leased several times. From 1980 to 1983 it was leased again by Candelaria Metals, Inc., of Bishop, Calif. Workings at several mines were reopened, and improvements to a mine haulage road were completed. Plans for mining and for millsite construction at the mouth of Queen Canyon were suspended when silver prices fell below $\$ 10$ per oz (Paul Spor, oral commun., 1982)

Prospecting in the late 1800 's led to several gold and mercury discoveries near Sugarloaf mountain. The most significant gold producer inside the roadless area was the Brownie mine. Production was continuous from 1908 to 1915 , and intermittent to 1941 . By 1915 the ores were processed on-site by a stamp mill and an amalgamation plant. Also by 1915, a 10-stamp mill with a 50-ton-per-day capacity was processing siliceous gold and silver ore at the Tip Top mine (Heikes, 1915). Production from this property, which is adjacent to the roadless area, ceased in 1919. During its short period of mining, it produced over $3,000 \mathrm{oz}$ of gold. After a 50- to 60-year period of little activity, Cordex Exploration Company located the Tip and leased the Gold claim groups, which include the Brownie and Tip Top mines, and started an evaluation program in 1980. Since then, the company has conducted geologic mapping and geochemical surveys, and collected samples from outcrops, mine and prospect workings, and 27 core-drill holes.

There is little historical data regarding the mercury properties near Sugarloaf mountain. The Wild Rose mine (Starlight) was one of the earliest discoveries, and was the only producer. West of Sugarloaf mountain, several properties in the northwest corner of the study area contain copper or silver minerals, or fluorite.

Trail Canyon was first prospected for mercury. The F and $\mathrm{L}$ mine and the Red Rose (Tiger claim) produced mercury ore from 1934 to 1942 . The $B$ and $B$ mine, adjacent to the roadless area, was the largest producer, followed by the Red Rock and Container mines, which are about $2 \mathrm{mi}$ to the southeast. Mercury-bearing rhyolite was roasted in crude retorts to recover mercury at the small mines. The larger mines had more sophisticated equipment, but the recovery processes were similar.

Interest in this area was renewed in the 1970's when Earth Sciences, Inc., applied to the U.S. Forest Service for a prospecting permit for alunite, which contains aluminum and potassium. Work by Earth Sciences, Inc., indicates two poorly defined alunite bodies. Exploration of the occurrence is still in a preliminary stage and there is no current activity. Extraction of aluminum from alunite is an economically unproven procedure.

U.S. Steel Corporation has located the Jon claim group, part of which covers the Red Rose and $F$ and $L$ mine sites. Since 1980, drill-hole, geologic, and geochemical data have been collected to determine if there are precious-metal deposits beneath the mercury-bearing zone.

Table 1 summarizes recorded production from the mines in and adjacent to the Sugarloaf Roadless Area.

\section{Mining claims}

At least 633 lode claims were located in or near the roadless area since 1862 . About 255 of these have been located between 1980 and 1982; many are included in the large Jon, Tip, and Beth claim groups. In 1975, Earth
Sciences, Inc., National Steel Corp., and the Southwire Company applied for prospecting permits for the MTC potassium and alunite property. This property covers 2,200 acres; 960 acres lie inside the roadless area and include the Red Rose (Tiger claim) and the $\mathrm{F}$ and $\mathrm{L}$ mercury mines. The Indian Queen-Poorman mine is located on the only patented claims inside the roadless area. The Tip Top mine is adjacent to patented ground (Buena Vista and Gold Standard) that is contiguous with the north boundary of the roadless area.

Summary descriptions of all properties examined during this investigation are included in table 2, along with an assessment of mineral resource potential. The names of several properties listed as "unknown prospect" in table 2 could not be identified by claim notices or through published literature.

\section{ASSESSMENT OF MINERAL RESOURCE POTENTIAL}

\section{Definitions}

The definitions of mineral resource classifications are from U.S. Bureau of Mines and U.S. Geological Survey (1980). The measured, indicated, and inferred categories, respectively, reflect decreasing knowledge of the characteristics of a deposit. For this report, an attempt has been made to further define subeconomic resources and resource potential. Deposits classified as reserves are deposits believed to be minable at a profit, under current economic conditions. Feasibility studies were conducted to substantiate this classification. Properties having marginal reserves would require improvement of economic conditions, as much as 50 percent increase in commodity price; or identification of a larger deposit for an equivalent reduction in unit production cost. Subeconomic resources would require a greater improvement in economic conditions and (or) identification of a larger deposit to be mined profitably. In this report, a subeconomic resource, if mined, is expected to return at least 20 percent of the cost of producing the commodity(s). In some cases, identified tonnage and grade estimated at a mining property may not be sufficient to support a resource classification, however, it would warrant that classification assuming consolidation and development with other properties.

The terms high, moderate, and low resource potential, as used in this report, reflect degrees of probability that undiscovered resources exist. The resource potential is based on assessment of published information, field examination of geologic features, geochemical sample analyses, and mine and prospect evaluation. The mineral resource potential of the Sugarloaf Roadless Area is summarized in figure 2.

\section{Areas and deposits}

Most of the eastern part of the roadless area is underlain by rhyolitic, dacitic, and andesitic rocks. Geochemical anomalies in this area consist predominantly of the element mercury. These anomalies, like most others in western Nevada, are closely and probably genetically related to Tertiary silicic igneous activity. Locally, as near Sugarloaf mountain, gold and silver mineralization is associated with quartz in a northeast-trending brecciated fault zone. Other faults in the volcanic rocks are not easily detected, but those recognized contain gold and mercury minerals in places. The extensive silicification and alunitization and the presence of mercury and fluorite are further indications of regional alteration of silicic volcanic rocks. Hydrothermal alteration on this large scale suggests the possibility of base and precious metalization at depth.

The western part of the roadless area contains Paleozoic metamorphic rocks, Mesozoic granitic rocks, and Tertiary volcanic rocks. Most of the stream-sediment and panned-concentrate samples from drainage basins in this part of the area contain significant anomalies for many of the elements that are indicative of hydrothermal alteration and (or) mineralization. The anomalous elements include silver, gold, and locally mercury and zinc in the stream-sediment samples, and silver, lead, and locally arsenic, gold, bismuth, cadmium, copper, tin, tungsten, and zine in panned- 
concentrate samples. Lead isotope studies of ores from Queen Canyon suggest that the metal source is from the nearby Jurassic plutons (Robert Zartman, oral commun., 1982).

The three parts of the Sugarloaf Roadless Area that have significant mineral resource potential are: (1) the southwestern part, particularly the Queen Canyon area, which has a moderate resource potential for silver and a low resource potential for lead, zinc, and copper; (2) the northcentral part, near Sugarloaf mountain, which has a low resource potential for gold, silver, and fluorspar; and (3) the southeastern part which has a low resource potential for mercury.

\section{Queen Canyon area}

The Indian Queen mine is the most important mining property in the Sugarloaf Roadless Area. A near-surface mineralized zone in Paleozoic phyllite is estimated to contain 170,000 tons of subeconomic resources at an average grade of $2.0 \mathrm{oz}$ silver per ton. There are about 10,000 tons of subeconomic resources averaging at least $2.0 \mathrm{oz}$ silver per ton in the old mine dumps. This mining property has a moderate potential for undiscovered silver resources and a low potential for lead, zinc, and copper resources.

In Queen Canyon a large group of claims, known as the Indian Queen project, covers several properties including the Indian Queen-Poorman mine. The part of this claim group in the roadless area has a low potential for silver, lead, zinc, and copper resources.

None of the mineral deposits in the Queen Canyon area are presently minable at a profit.

\section{Sugarloaf mountain area}

The most important property in this area is the Brownie mine. Only a small segment of the mineralized zone was accessible; from these limited exposures a total of 8,800 tons of indicated and inferred subeconomic resources with an average grade of $0.21 \mathrm{oz}$ gold per ton was estimated. This property has a moderate potential for additional gold and silver resources.

There are several widely spaced fluorspar properties in and adjacent to the west boundary of the roadless area. Date was insufficient to estimate tonnage and grade. The resource potential for fluorspar is low at the Fluorspar No. 1 and the unknown (SE 1/4 sec. 18, T. 1 S., R. 33 E.) prospects.

\section{Trail Canyon area}

The $\mathrm{F}$ and $\mathrm{L}$ mine is the most important mine in this area. It has 200,000 tons of mercury-bearing rhyolite averaging $0.8 \mathrm{lb}$ mercury per ton. This property has a low potential for mercury resources.

Alunite (hydrous potassium aluminum sulfate) occurs in the southeast corner of the study area, but little is known about extent or grade of the deposit. Extraction of alumina from alunite is an economically unproven procedure.

\section{REFERENCES}

Bailey, E. H., and Phoenix, D. A., 1944, Quicksilver deposits in Nevada: Nevada University Bulletin, v. 38, no. 5, Geology and Mining Series 41, $206 \mathrm{p}$.

Centanni, F. A., Ross, A. M., and De Sesa, M. A., 1956, Fluorimetric determination of uranium: Analytical Chemistry, v. 28, no. 11, p. 1651-1657.

Crowder, D. F., Robinson, P. T., and Harris, D. L., 1973, Geologic map of the Benton quadrangle, Mono County, California, and Esmeralda and Mineral Counties, Nevada: U.S. Geological Survey Geologic Quadrangle Map GQ-1013, scale 1:62,500.

Donahoe, J. L., and Chaffee, M. A., 1983, Geochemical anomaly map of the Sugarloaf Roadless Area, Esmeralda and Mineral Counties, Nevada: U.S. Geological Survey Miscellaneous Field Studies Map MF-1400-B, scale 1:62,500.
Grimes, D. J., and Marranzino, A. P., 1968, Direct-current arc and alternating-current spark emission spectrographic field methods for the semiquantitative analysis of geologic materials: U.S. Geological Survey Circular 591, $6 \mathrm{p}$.

Heikes, V. C., 1915, Mineral resources of the United States: Part I, U.S. Geological Survey, 1,000 p.

Holmes, G. H., Jr., 1965, Mercury potential of the United States, Chapter 8: U.S. Bureau of Mines Information Circular 8252, 376 p.

Horton, R. C., 1961, An inventory of fluorspar occurrences in Nevada: Nevada Bureau of Mines Report 1, 31 p.

Lincoln, F. C., 1923, Mining districts and mineral resources of Nevada: Reno, Nevada Newsletter Publishing Company, p. 140-141.

McKee, E. H., 1982, Geologic map of the Sugarloaf Roadless Area, Esmeralda County, Nevada: U.S. Geological Survey Miscellaneous Field Studies Map MF-1400-A, scale $1: 62,500$.

Meier, A. L., 1980, Flameless atomic-absorption determination of gold in geological materials: Journal of Geochemical Exploration, v. 13, no. 1, p. 77-85.

Robinson, P. T., and Crowder, D. F., 19731974 , Geologic map of the Davis Mountain quadrangle, Esmeralda and Mineral Counties, Nevada, and Mono County, California: U.S. Geological Survey Geologic Quadrangle Map GQ-1078, scale 1:62,500.

Schmauch, S. W., Horn, M. C., and Winters, R. A., 1983, Mineral resources of the Sugarloaf, Nevada, RARE II AREA (No. 5296), Esmeralda and Mineral Counties, Nevada: U.S. Bureau of Mines Open-File Report MLA 96-83.

U.S. Bureau of Mines and U.S. Geological Survey, 1980, Principles of a resource/reserve classification for minerals: U.S. Geological Survey Circular 831, 5 p.

Ward, F. N., Nakagawa, H. M., Harms, T. F., and VanSickle, G. H., 1969, Atomic-absorption methods of analysis useful in geochemical exploration: U.S. Geological Survey Bulletin 1289, 45 p.

Whitehill, H. R., 1875-76, Biennial report of the state mineralogist of the State of Nevada State: 1875 and 1876,226 p.

Whiting, H. A., 1888, Mono County, eighth annual report of the state mineralogist: California State Mining Bureau, p. 377.

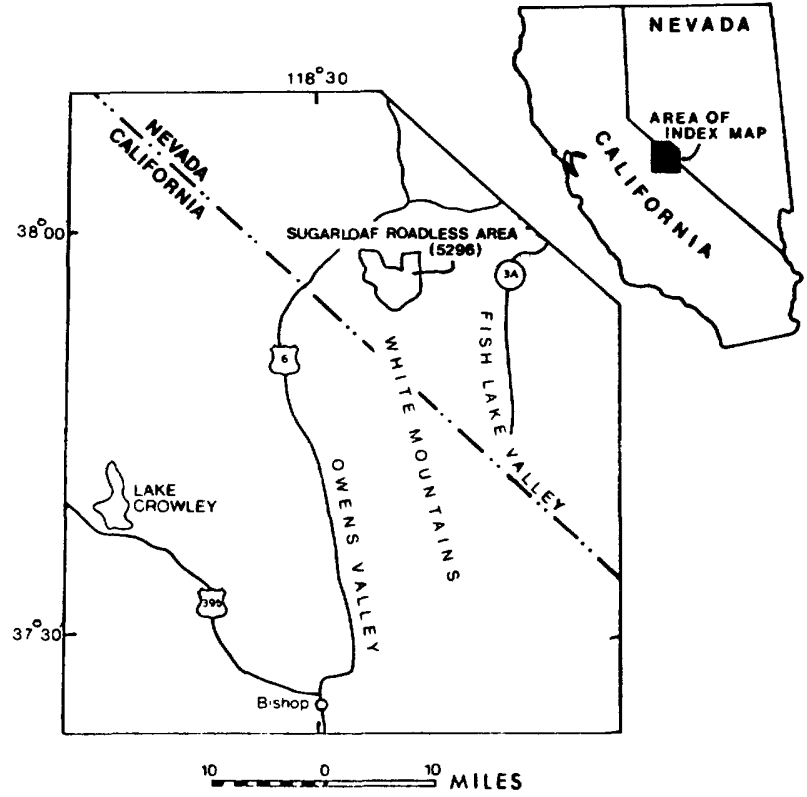

Figure 1.--Index map showing location of the Sugarloaf Roadless Area (5296), Nev. 


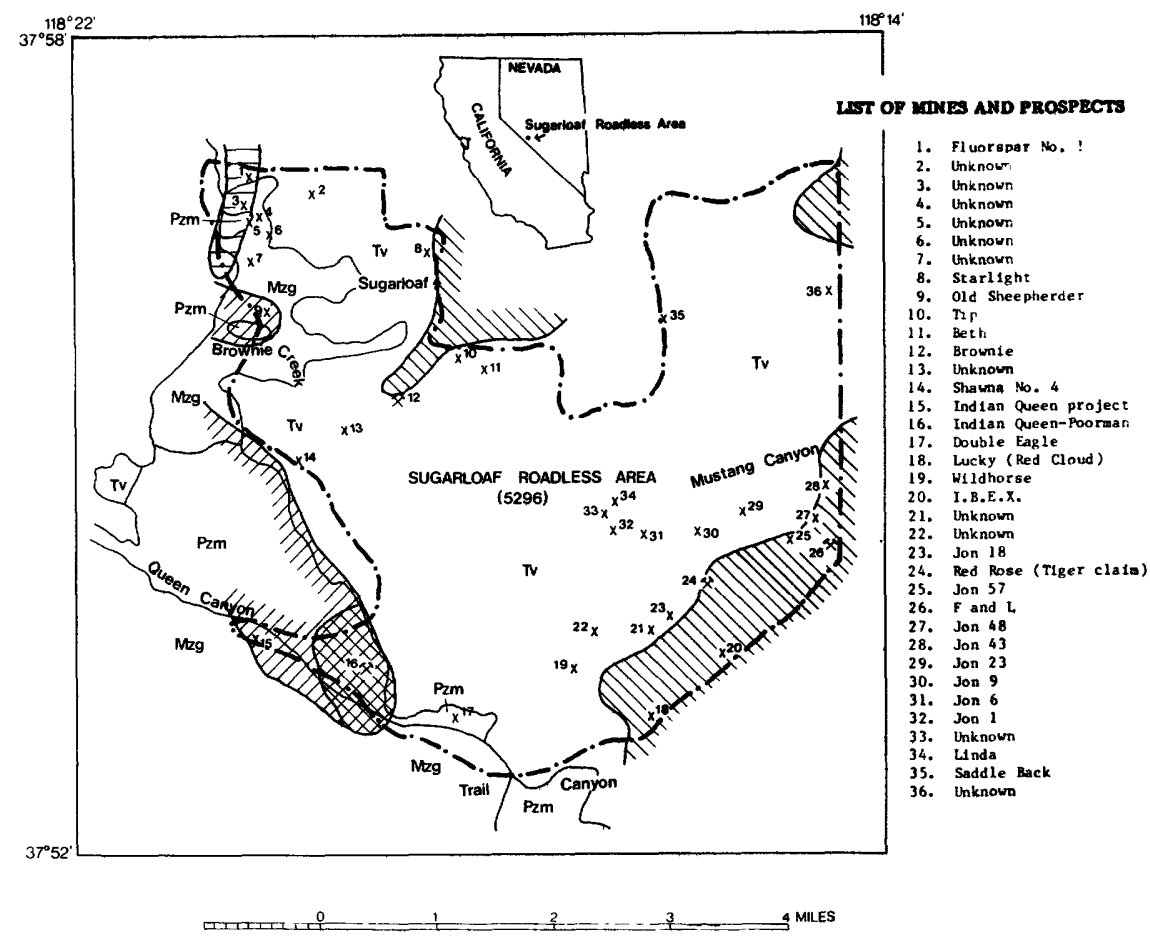

EXPLANATION

MINERAL RESOURCE POTENTIAL

Area with moderate resource potential for silver (hydrothermal vein type in metamorphic rocks near granitic plutonic rocks)

Area with low resource potential for silver (hydrothermal veln type in metamorphic rocks near granitic plutonic rocks)

Area with low resource potential for mercury and gold (hydrothermal vein type In sillcic volcanic rocks)

Area with low resource potential for fluorite (vein deposits related to silicic volcanic rocks)
GEOLOGIC UNITS

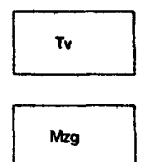

Volcanic rocks (Tertiary)

Granitic rocks (Mesozoic)

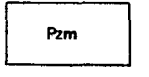

Metasedimentary rocks

(Paleozoic)

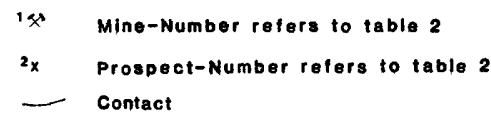

Contact

- Approximate boundary of roadless area

Figure 2.--Simplified geologic map showing areas of mineral resource potential and mines and prospects, Sugarloaf Roadless Area, Nev. 
Table 1.--Recorded production from lode deposits in and adjacent to the Sugarloaf Roadless Area [From U.S. Bureau of Mines production files; underlined properties are inside the area; NR, not reported]

\begin{tabular}{|c|c|c|c|c|c|}
\hline Property & Yea $r(s)$ & Tons & $\begin{array}{l}\text { Gold } \\
(\mathrm{oz})\end{array}$ & $\begin{array}{l}\text { Silver } \\
(\mathrm{oz})\end{array}$ & $\begin{array}{c}\text { Mercury } \\
(76-1 b \text { flasks })\end{array}$ \\
\hline$B$ and $B$ mine & $1927-1969$ & 108,873 & NR & NR & 7,158 \\
\hline$\frac{\text { Brownie mine }}{\text { (Gold Nos. 1-6) }}$ & $1908-1941$ & 2,682 & 393.4 & 327 & NR \\
\hline$F$ and $L$ mine & $1937-1941$ & 125 & NR & NR & 13 \\
\hline King-B1ue Bel1 minel & 1937 & 200 & NR & NR & NR \\
\hline Indian Queen-Poorman mine ${ }^{2}$ & $1870-1958$ & 1,163 & 91.8 & 108,871 & NR \\
\hline$\frac{\text { Red Rose mine }}{\text { (Tiger claim) }}$ & $1934-1942$ & NR & NR & NR & 1 \\
\hline $\begin{array}{l}\text { OK mine (Pinchot Canyon } \\
\text { or Esmeralda) }\end{array}$ & 1941 & 30 & NR & NR & 7 \\
\hline $\begin{array}{l}\text { Tip Top mine } \\
\text { (Thorndyke and Bley) }\end{array}$ & $1912-1919$ & 7,383 & $3,220.0$ & 19,736 & NR \\
\hline $\mathrm{L}$ and $\mathrm{D}$ mine & $1943-1944$ & 60 & NR & NR & 26 \\
\hline Buckskin mine & 1956 & NR & NR & NR & 2 \\
\hline $\begin{array}{l}\text { Wild Rose mine }{ }^{3} \\
\text { (Red Rose mines) } \\
\text { (Starlight) } \\
\text { (Mount Montgomery) }\end{array}$ & $1916-1931$ & 112 & NR & NR & 163 \\
\hline $\begin{array}{l}\text { Total in roadless area } \\
\text { Total in and adjacent to }\end{array}$ & badless area & $\begin{array}{r}4,047 \\
120,588\end{array}$ & $\begin{array}{r}485.2 \\
3,705.2\end{array}$ & $\begin{array}{l}109,198 \\
128,934\end{array}$ & $\begin{array}{r}38 \\
7,394\end{array}$ \\
\hline
\end{tabular}

\footnotetext{
${ }_{2}^{1}$ Fluorspar, grade unknown.

2 Exact production figures are not available; amounts reported here are from 1876 to 1914. The Indian Queen-Poorman mine also produced $161,5351 \mathrm{~b}$ of lead, 31,062 $1 \mathrm{~b}$ of copper, and $543 \mathrm{lb}$ of $\mathrm{zinc}$ during this same time period. Mines in Queen Canyon which may have had production attributed to Indian QueenPoorman mine or reported as Queen Canyon area production include: Albert mine, Morgan (Diana) mine, Spohr mine, Queen Canyon mine, Maley tunnel, and Mathieu tunnel. Whitehil1 (1875-76) attributes production of gold, silver, lead, zinc, and copper worth $\$ 1$ million to the Indian Queen mine.

This property was first known as Mount Montgomery in 1916. It was later known as the Red Rose from 1919 to 1931 [not to be confused with the Red Rose mine (Tiger claim)]. It was called Starlight group in 1929 and 1957, and the Starlight in 1981. Bailey and Phoenix (1944, p. 74) state that the Wild Rose mine produced 163 flasks of mercury by the end of 1943.
} 


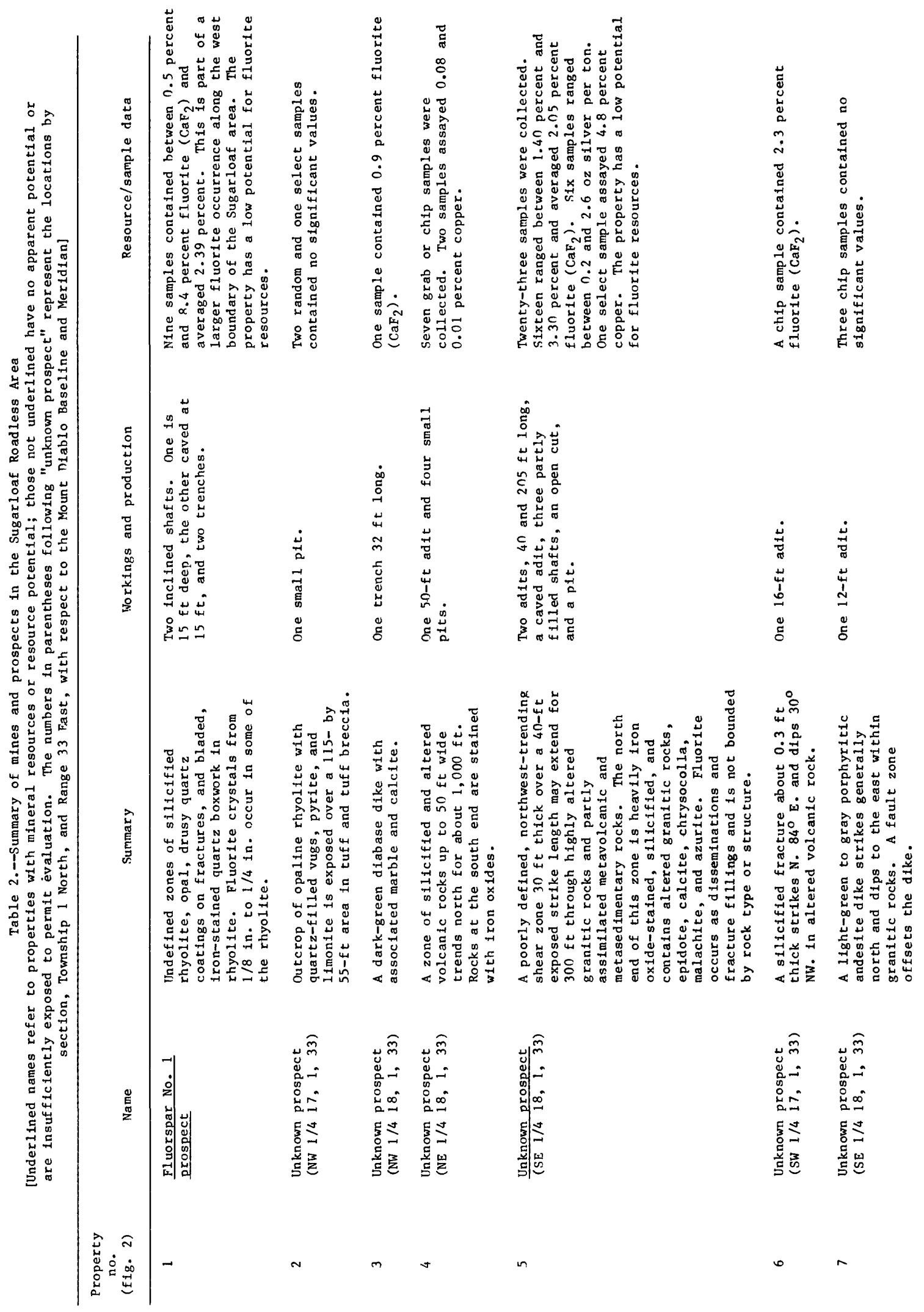




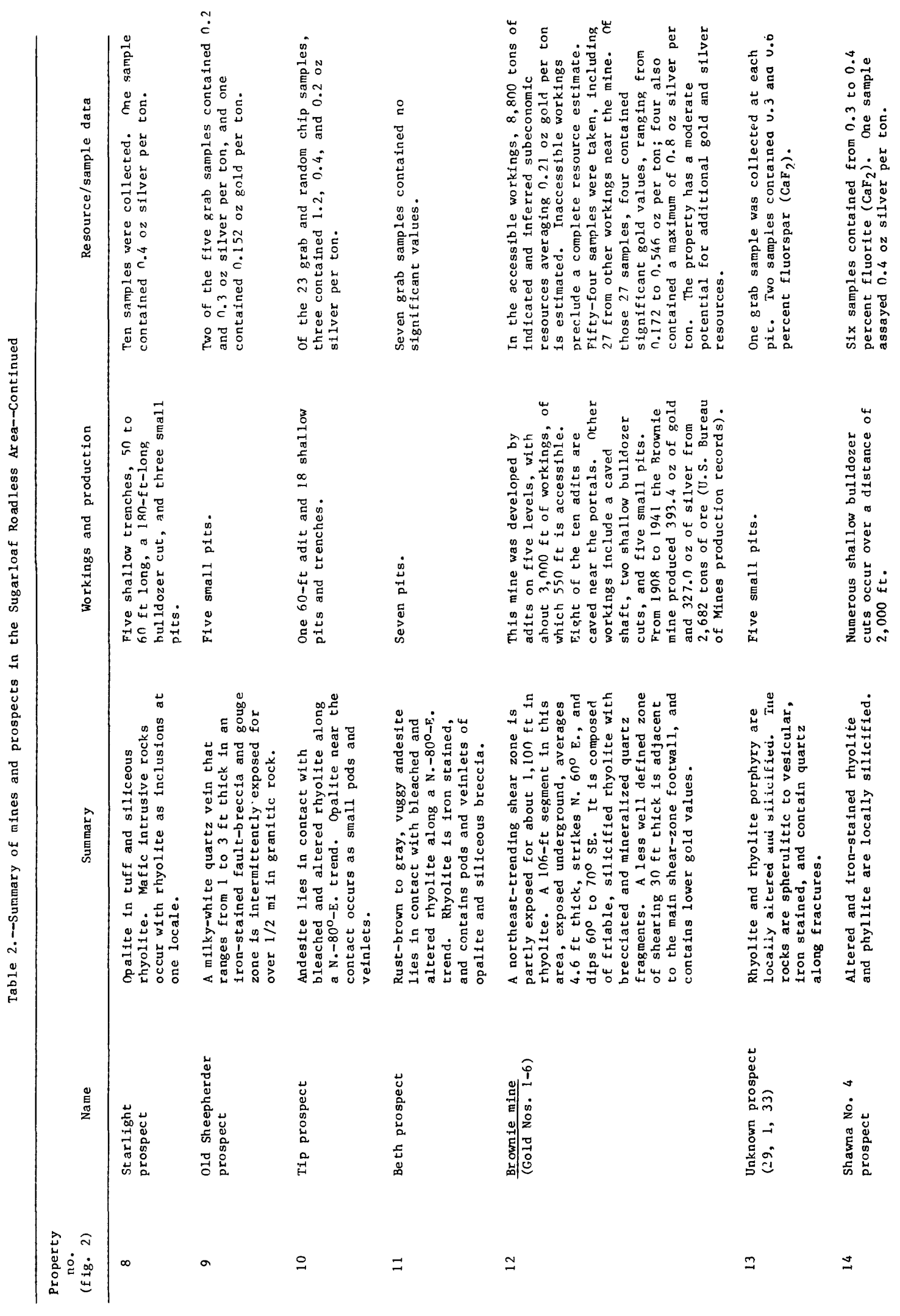




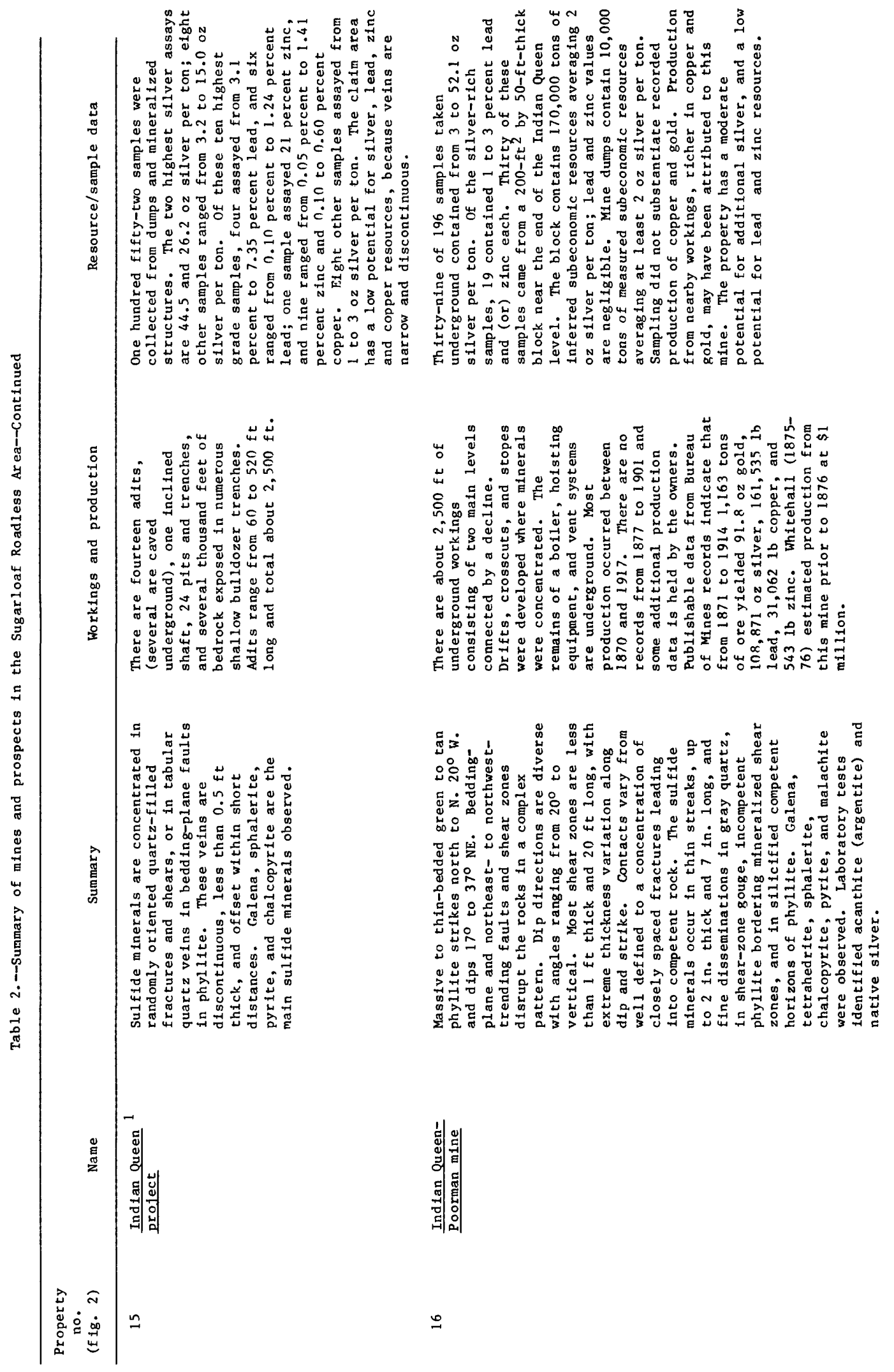




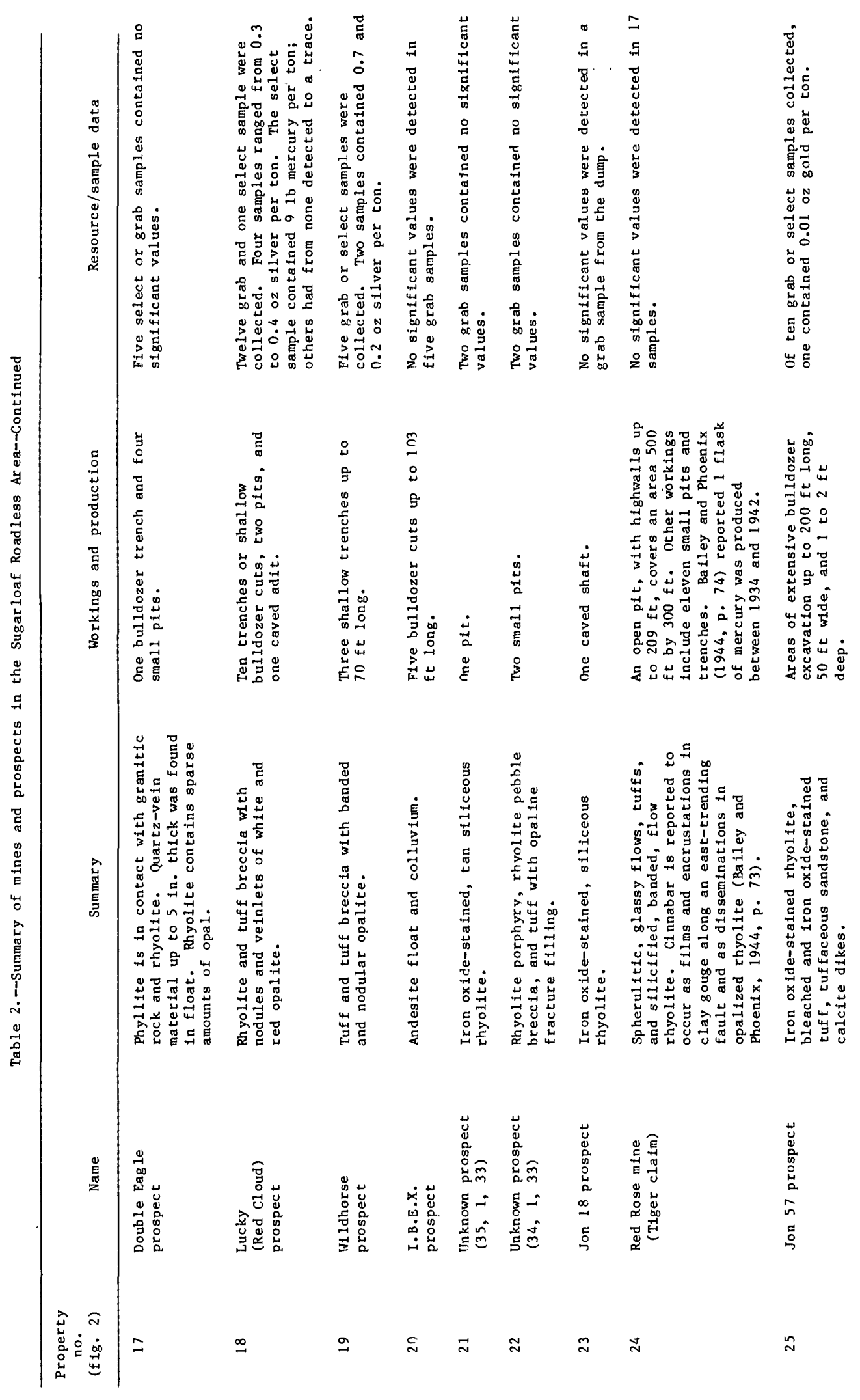




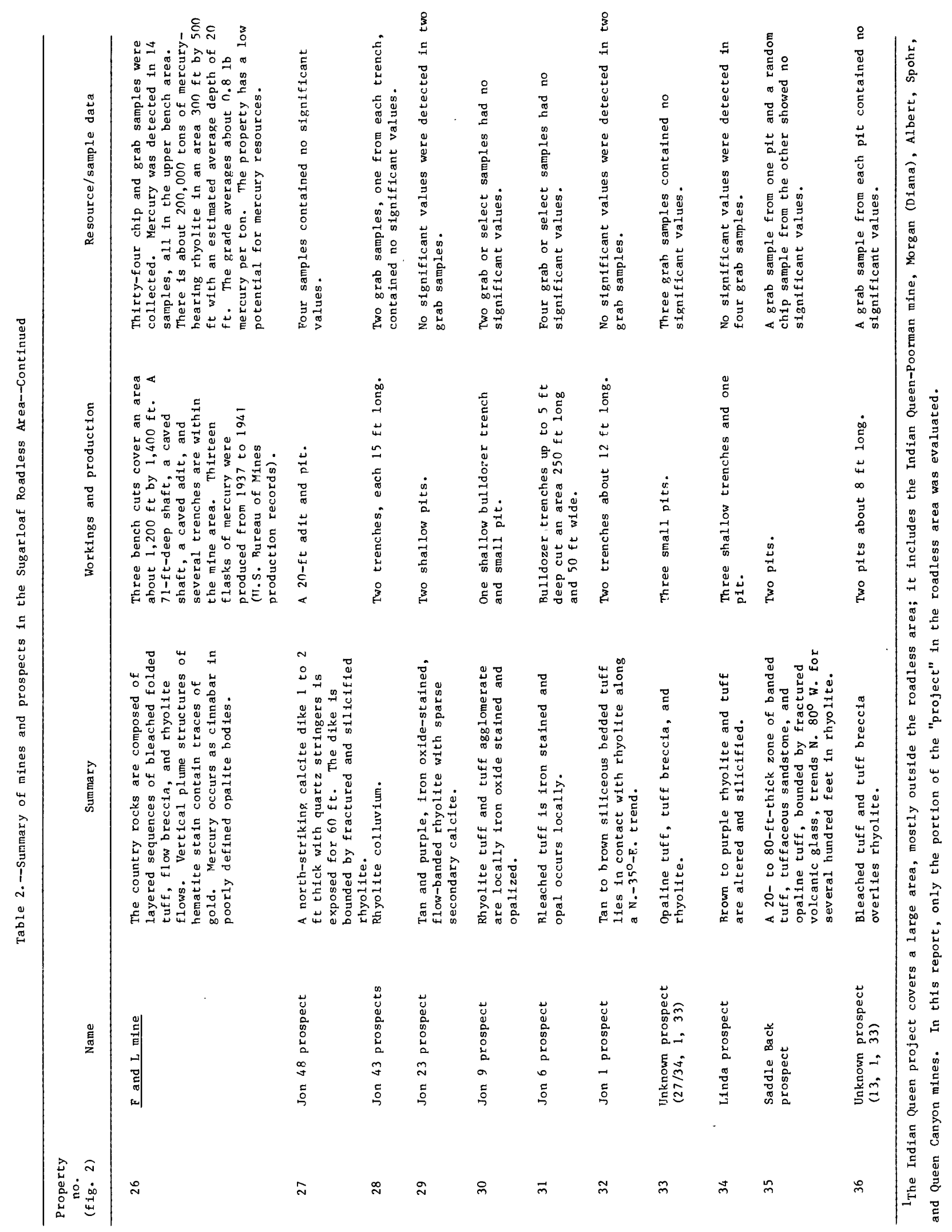


